\title{
Long-term monitoring of temperate macroalgal assemblages inside and outside a No take marine reserve
}

\author{
Alba Medrano ${ }^{\text {a, *, Cristina Linares }}{ }^{\text {a }}$, Eneko Aspillaga ${ }^{\mathrm{a}, \mathrm{b}}$, Pol Capdevila ${ }^{\mathrm{a}, \mathrm{c}}$, \\ Ignasi Montero-Serra ${ }^{a}$, Marta Pages-Escola ${ }^{a}$, Mikel Zabala ${ }^{a}$, Bernat Hereu ${ }^{a}$ \\ ${ }^{a}$ Department of Evolutionary Biology, Ecology and Environmental Sciences, Institut de Recerca de la Biodiversitat (IRBIO), University of Barcelona, Av. Diagonal 643, \\ 08028, Barcelona, Spain \\ ${ }^{\mathrm{b}}$ Department of Marine Ecology, Institut Mediterrani d'Estudis Avançats, IMEDEA (CSIC-UIB), C/Miquel Marques 21, 07190, Esporles, Balearic Islands, Spain \\ ${ }^{\mathrm{c}}$ Department of Zoology, Oxford University, Oxford, OX1 3PS, UK
}

\section{A R T I C L E I N F O}

\section{Keywords:}

Community ecology

Marine reserve

Monitoring

Seaweeds

Temporal dynamic

\begin{abstract}
A B S T R A C T
Macroalgal communities have an essential role in the shallow benthic habitats of temperate seas, where changes in their composition can resonate through entire coastal ecosystems. As all major ecosystems on Earth, algal beds have already been affected by multiple disturbances. Passive conservation tools, such as marine protected areas or No-take zones, have the potential to reduce some of the anthropogenic impacts by limiting human activity. However, without a good knowledge of the natural community dynamics, it is not easy to discern between changes fruit of the intrinsic variability of biological communities and the ones caused by human-related stressors. In this study, we evaluated the natural variability of macroalgal communities' composition inside and outside a Mediterranean No-Take marine reserve during 15 years. We described their temporal dynamics considering their main drivers and we tested the effect of protection in seaweed beds. We did not find differences either in the composition of the macroalgal assemblages or the total algal cover between protected and nonprotected locations over the fifteen years of study. Nevertheless, we observed a positive effect of the protection increasing the cover of some specific species, such as the canopy-forming Treptacantha elegans. Our results highlight the importance of obtaining long-term data in ecological studies to better understand the natural variability of marine communities. Accordingly, a robust understanding of the community dynamics would help us to avoid misinterpretations between 'impacted' or 'in-recovery' communities when recovery times are longer than the study periods.
\end{abstract}

\section{Introduction}

Global and local human disturbances have affected all major ecosystems on Earth, including coastal algal communities (Halpern et al., 2007; Gianni et al., 2017), the dominant primary producers in the coastal zone (Krause-Jensen and Duarte, 2016). Overfishing, global warming, and exceptional storms further contribute to transforming rocky infralittoral algal habitats (Ling et al., 2009; Smale and Vance, 2016; Wernberg et al., 2016; Maggi et al., 2018). Conservation tools such as Marine Reserves or No-Take Zones (NTZ) have the potential to reduce some of these anthropogenic disturbances (i.e, banning fishery activities) and to restore benthic habitats through trophic cascade effects (Shears and Babcock, 2002; Guidetti, 2006; Babcock et al., 2010).

Macroalgae play a key role in the structure of temperate benthic ecosystems (Jones et al., 1994; Duarte and Cebrian, 1996; Teagle et al., 2017), representing an important source of carbon sequestration (Krause-Jensen and Duarte, 2016) and providing invaluable ecosystem services in many shallow coastal systems (Blamey and Bolton, 2018). Consequently, changes in macroalgal communities may sway in the whole coastal ecosystem (Mineur et al., 2015). In the Mediterranean Sea, algal communities dominate the shallow benthic habitats (Zabala and Ballesteros, 1989). There, the highest level of structural complexity is represented by canopies of fucoid algae, mostly Cystoseira sensu lato populations, providing habitat, shelter, and food to many associated organisms and harboring a high diversity and productivity (Ballesteros et al., 1998; Mangialajo et al., 2008; Sala et al., 2012; Cheminee et al., 2013). Water pollution, modifications of natural rocky coastline, and sea urchin overgrazing as a consequence of overfishing are the major drivers

\footnotetext{
* Corresponding author.

E-mail addresses: amedrano@ub.edu, albamedranocuevas@gmail.com (A. Medrano).
} 
of the loss of fucoids in the Mediterranean Sea (Airoldi and Beck, 2007; Mineur et al., 2015). Consequently, severe declines of macroalgal forests (i.e. Cystoseira spp.) have been documented, with the consequent changes in the associated species, and effects cascading up to higher trophic levels (Ling et al., 2015; Cheminee et al., 2013).

Long-term ecological studies observing natural communities dynamics under the human influence are essential to understand the operation of natural systems, and most especially, to know the communities' baseline before describing pressures or impacts. Changes in marine benthic communities and conservation effects are usually reported in 'before-after' studies or with 'snapshots' of the protected area vs. the unprotected one, while long-term monitoring programs are focused on specific species or populations, such as corals, seagrasses, sea urchins or kelp species among others (e.g. Kirkman and Kirkman, 2000; Steneck et al., 2002; Babcock et al., 2010; Gross and Edmunds, 2015). Despite the essential role of macroalgal beds in benthic communities, there is an important lack of continuous and long-term studies that integrate community changes together with their long-term dynamics and with the conservation role, without which we can misinterpret communities alterations.

In this study, we annually monitored infralittoral macroalgal communities inside and outside a NTZ located in the North-Western Mediterranean Sea during 15 years. Benthic shallow-rocky habitats in the study area are mostly represented by photophilic algal communities of small and erect algae (e.g., Dyctiota spp.) and calcareous algal formations (Ballesteros, 1991). The sea urchin Paracentrotus lividus is the main herbivorous species that control algal biomass (Hereu et al., 2012; Medrano et al., 2019). Abundance and temporal trends on sea urchin populations were similar inside and outside the studied NTZ (Hereu et al., 2012) until an exceptionally violent storm occurred in 2008 that drastically reduced sea urchin densities. After that, the populations of the sea urchin $P$. lividus outside the NTZ recovered faster than the population inside the NTZ (Medrano et al., 2019). The present study aims to describe the temporal dynamics of the macroalgal communities considering their main drivers and environmental stressors and to evaluate the effect of protection in macroalgal beds over time by analyzing long-term monitoring data.

\section{Methods}

\subsection{Monitoring and study area}

Shallow rocky infralittoral macroalgal communities were monitored at eight localities in the Montgrí, the Illes Medes and the Baix Ter Natural Park, located in the North-Western Mediterranean Sea (Fig. 1). Within the Natural Park, four out of the eight sampled localities were placed inside the Medes Islands No-Take Zone (NTZ) and, the other four, outside the boundaries of the NTZ (Fig. 1).

To monitor macroalgal communities, we annually sampled the algal assemblage structure based on the main seaweed species (Table 1) from 2001 to 2016, excluding the years 2006, 2007, 2011 and 2015. The algal percent cover was visually quantified using $50 \quad 50 \mathrm{~cm}$ quadrats divided into 25 subquadrats of $10 \quad 10 \mathrm{~cm}$ (Hereu et al., 2008). Twenty replicate quadrats were randomly counted at each location at depths between 5 and $10 \mathrm{~m}$ by SCUBA divers. At each quadrat, each species percentage cover was estimated as the percentage of the numbers of subquadrats where the species was present relative to the total number of subquadrats sampled (as described in Sala and Ballesteros, 1997 and Hereu et al., 2008). To avoid the effect of seasonality, sampling was always performed at the end of May, when the most representative macroalgae (perennial and seasonal species) reach the maximum biomass in the study area (Sala and Boudouresque, 1997).

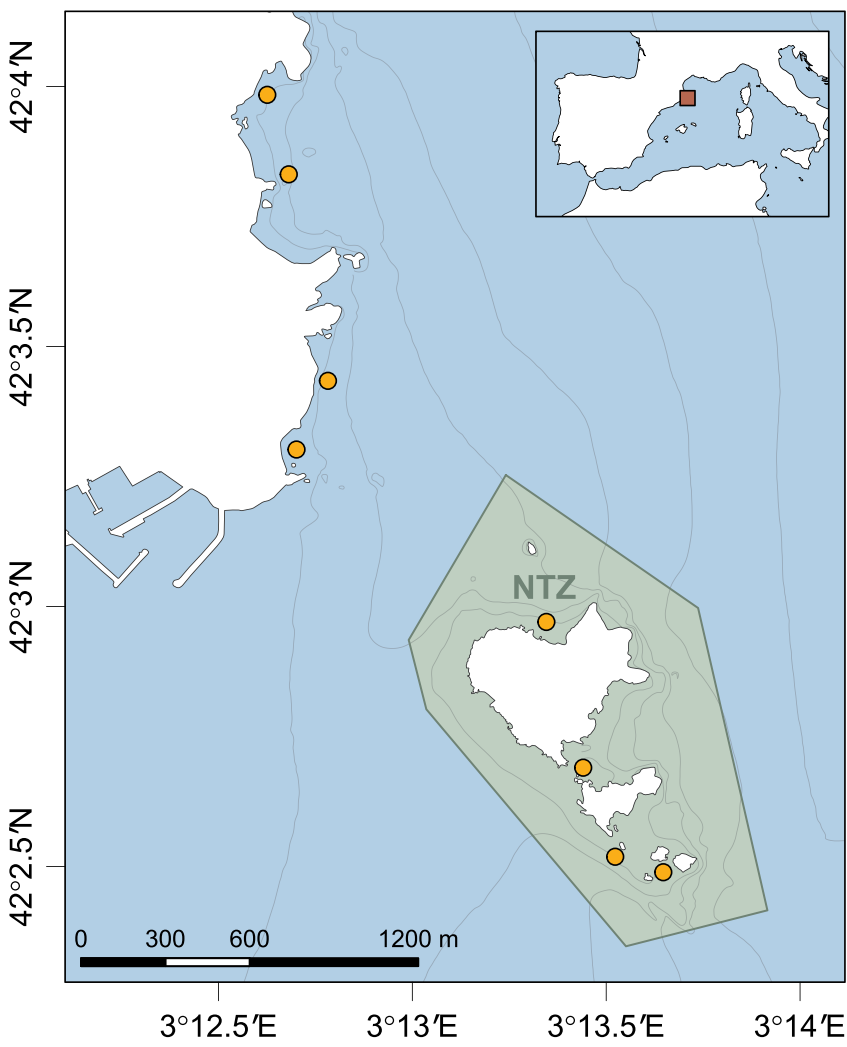

Fig. 1. Map of the study sites in the Montgrí, the Illes Medes, and the Baix Ter Natural Park (NW Mediterranean Sea). Orange dots represent the long-term monitoring sites: four are located outside the NTZ, and four more are inside the Medes Islands NTZ. The perimeter of the Medes Islands NTZ is delimited by the green polygon. Unprotected zone is outside the green polygon. (For interpretation of the references to color in this figure legend, the reader is referred to the Web version of this article.)

\subsection{Environmental drivers and stressors determining algal assemblage structure}

To investigate the relation between the composition of the macroalgal assemblages and the effect of the environmental drivers inside and outside the NTZ, we used Redundancy Analysis (RDA) (Van Den Wollenberg, 1977) on fourth-root transformed percentage cover data of all the monitored macroalgal species (Table 1). The RDA is a multivariate analysis technique which allows to introduce explanatory (environmental) variables considering multiple regressions to determine linear combinations of these variables with the dependent variables (seaweeds). Water nutrients, sea-surface temperature, sea urchin abundance, and level of protection (as categorical variable) were included as environmental variables (adapted from Hereu et al., 2008).

Specifically, Chlorophyll-a (Chl-a) levels are a good proxy for nutrient levels in coastal waters (Brodie et al., 2007). Therefore, Chl-a data from the MODIS-Aqua sensor were extracted for the monitored area with a $4 \mathrm{~km}$ resolution from NASA Giovanni (MODISA_L3m_CHL_v2018; https://giovanni.gsfc.nasa.gov/giovanni/) from 2002 (starting date of this time-series) to 2016. In order to relate the nutrient concentration with the sampled algae cover, the average concentration of Chl-a $\left(\mathrm{mg} / \mathrm{m}^{3}\right)$ was calculated for the spring season of each sampled year (March to May).

Sea-surface temperature (SST) data were obtained from the L'Estartit Meteorological Station (http://meteolestartit.cat/mar/temperatura/), where temperature has been measured $1.7 \mathrm{~km}$ offshore of the Medes Islands NTZ (the northwestern Mediterranean, $4203^{\prime} \mathrm{N} 315^{\prime} 15^{\prime \prime} \mathrm{E}$ ) since 1974. Like Chl-a, we have considered here the mean SST of the spring season (March to May) for each year from 2001 to 2016. 
Table 1

List of the main macroalgal species present in the study area and included in the anual monitoring: full names, abbreviations, and authorities. The species in bold represent about $90 \%$ of total algal cover and were considered here as the fourteen major species.

\begin{tabular}{|c|c|c|}
\hline \multicolumn{3}{|l|}{ Rhodophyta } \\
\hline Amphiroa rigida & Amphiroa & Lamouroux \\
\hline Asparagopsis armata & Asparagopsis & Harvey \\
\hline $\begin{array}{l}\text { Bonnemaisonia } \\
\text { asparagoides }\end{array}$ & Bonnemaisonia & (Woodward) C. Agardh \\
\hline Ceramium ciliatum & Ceramium & Ducluzeau \\
\hline Corallina elongata & Corallina & $\begin{array}{l}\text { Ellis and Solander (also accepted as } \\
\text { Ellisolandia elongata) }\end{array}$ \\
\hline Gelidium spinosum & Gelidium & (Gmelin) Silva \\
\hline Jania rubens & Jania & (Linnaeus) Lamouroux \\
\hline Laurencia obtusa & Laurencia & (Hudson) Lamouroux \\
\hline Liagora viscida & Liagora & (Forsskal) C. Argardh \\
\hline $\begin{array}{l}\text { Lithophyllum } \\
\text { incrustans }\end{array}$ & L.incrustans & Philippi \\
\hline $\begin{array}{l}\text { Mesophyllum } \\
\text { alternans }\end{array}$ & M.alternans & (Foslie) Cabioch and Mendoza \\
\hline Peyssonnelia bornetii & Peysonnelia & Bourderesque and Denizot \\
\hline $\begin{array}{l}\text { Sphaerococcus } \\
\text { coronopifolius }\end{array}$ & Sphaerococcus & $\begin{array}{l}\text { (Goodenough and Woodward) } \\
\text { Stackhouse }\end{array}$ \\
\hline Wrangelia penicillata & Wrangelia & C. Agardh \\
\hline \multicolumn{3}{|l|}{ Phaeophyta } \\
\hline Cladostephus spongiosus & Cladostephus & (Hudson) C. Agardh \\
\hline Colpomenia sinuosa & Colpomenia & (Mertens ex Roth) Derbes and Solier \\
\hline Cystoseira compressa & C.compressa & (Esper) Gerloff and Nizamuddin \\
\hline Treptacantha elegans & T.elegans & Sauvageau \\
\hline Dictyota spp & Dictyota & \\
\hline Halopteris scoparia & Halopteris & (Linneaus) Sauvageau \\
\hline Padina pavonica & Padina & (Linneaus) Thivy \\
\hline Zanardinia typus & Zanardinia & (Nardo) Furnari \\
\hline \multicolumn{3}{|l|}{ Chlorophyta } \\
\hline $\begin{array}{l}\text { Acetabularia } \\
\text { acetabulum }\end{array}$ & Acetabularia & (Linnaeus) Silva \\
\hline Codium bursa & C.bursa & (Linnaeus) C. Agardh \\
\hline Codium effusum & C.effusum & (Rafinesque) Delle Chiaje \\
\hline Codium vermilara & C.vermilara & (Olivi) Delle Chiaje \\
\hline Flabellia petiolata & Flabellia & (Turra) Nizamuddin \\
\hline Halimeda tuna & Halimeda & (Ellis and Solander) Lamouroux \\
\hline Ulva rigida & Ulva & C. Agardh \\
\hline
\end{tabular}

We used the same physical environmental variables (Chla- and SST) for locations inside and outside the NTZ, given that the average distance between the locations is lower than the spatial resolution of the described physical environmental variables $(2 \mathrm{~km})$.

The effect of protection on fish communities and the sea urchin abundance inside and outside the Medes Islands NTZ over the studied period were obtained from the long-term monitoring program of the Montgrí, the Illes Medes and the Baix Ter Natural Park (Medrano et al., 2019). Sea urchins missing data of the years 2006, 2007, 2014 and 2015 were linearly interpolated from the known values in the time-series. It is important to note that higher fish abundance and biomass of the main sea urchin predator species have remained significantly larger inside the NTZ than outside (García-Rubies and Zabala 1990; Sala, 1997; Hereu, 2005; Sala et al., 2012), with higher predation rates of sea urchins observed inside the NTZ over the last years (Sala, 1997; Hereu, 2005, 2012). Contrarily, no clear effect of protection on the unique herbivorous fish in the area, Sarpa salpa, was observed in rocky bottoms (Macpherson et al., 2002; Hereu et al. non pub. data).

The collinearity of the four variables was checked. Although the maximum correlation was found between the variables Sea urchin abundance and Protection level (Spearman correlation: 0.7), we considered and included all four variables as reasonably explanatory in this study.
2.3. Long-term trends of the main macroalgal species inside and outside the NTZ

The fourteen most representative algal species (representing a total cover of $890.06 \%$ (Mean SD) in the studied monitoring period, Table 1 bolded species) were selected to describe the temporal patterns of the macroalgal dynamics across protection levels and time. To show a clearer global view rare species were excluded. First, kite diagrams of the percentage of the main algal cover were plotted to visualize the changes of these algal assemblages over the studied period inside and outside the NTZ. Second, to assess the abundance variability throughout the studied period inside and outside the NTZ, we calculated the coefficient of variation (CV) of the algal relative abundance in each location. $\mathrm{CVs}$ of the fourteen most representative macroalgae were estimated as the mean CV of each species between the monitoring sites and CVs of the assemblages between protection levels were estimated with the fourteen CVs mean of each site. To test pairwise comparisons among CV, we used Tukey's Honestly Significant Differences (HSD) test in each pair of means (inside/outside NTZ). Finally, to test for differences in overall macroalgal assemblage structure among protection and time, we used multivariate generalized linear models implemented in the manyglm function of the mvabund R package (Wang et al., 2017). The macroalgal abundance in each monitored site was fitted as the response variable with a negative binomial distribution after visually checked the most likely distribution of the data. The variables protection (inside/outside NTZ) and time (years) were included as main fixed effects in the model. We then ran a univariate analysis of variance to test the significance of the effects in every algal species (Wang et al., 2017).

All statistical analysis and plots were run with the software R 3.3.3 (R Core Team, 2017). Multivariate analyses were performed with the $R$ package 'vegan' (Oksanen et al., 2017) and R Package 'mvabund' (Wang et al., 2017).

\section{Results}

\subsection{Environmental drivers and stressors determining algal assemblage strucure}

The first two axes of the RDA explained the $68 \%$ of the speciesenvironment relationship (Fig. 2A RDA, Table 2). The four biotic and abiotic variables were significantly correlated with the RDA axes. Protection and Sea urchins were strongly correlated with the first axis, while environmental variables related to seasonality (SST and Chl-a) were significant correlated with the second axis (Table 3).

Along the first axis, species positioned at the far right end were more abundant in protected sites with low abundance of sea urchins (e.g., Asparagopsis armata and Treptacantha elegans). These species were separated from those most commonly observed in non-protected sites, which were correlated with higher abundances of sea urchins (e.g., Wrangelia penicillata, Lithophyllum incrustans, Peyssonnelia bornetii). In line with that, the species identified as canopy-forming (Cystoseira sensu lato species) were positioned in the right side of the axis, while the encrusting coralline algae were on the left side (e.g, Lithophyllum incrustans and M. alternans). Along the second axis, the macroalgal seasonal species (spring-growing) related to the spring nutrient peak and cold waters were positioned in the top of the RDA biplot (e.g., Dictyota spp., Bonnemaisonia asparagoides, and Ulva rigida). Despite being a seasonal growing alga, since Laurencia obtusa biomass peak takes place during the late spring-early summer, it was mostly related to warm waters as well as the perennial Codium species (Fig. 2A).

Macroalgal assemblages inside and outside the NTZ shifted towards the same ordination space over time, highlighting inter-annual variability of the assemblage, and homogeneous patterns of change in both protection levels (Fig. 2B). Despite this observed variability, the last dot (representing 2016 data) was located close to the origin dot (representing 2003 data), indicating that no major shifts in the algal 

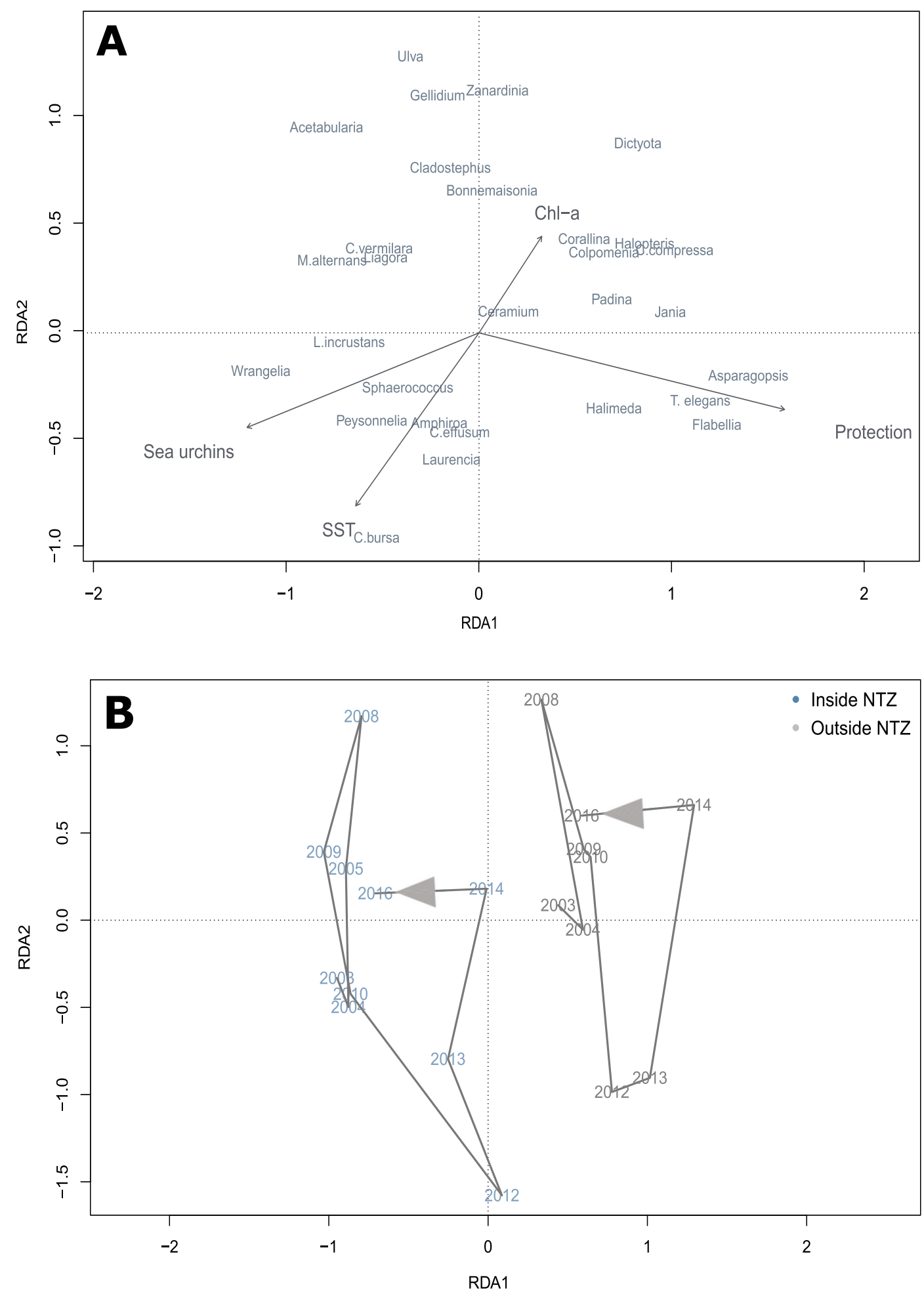

Fig. 2. (A) Redundancy Analysis ordination for macroalgal cover data over time. Blue dots are sampling sites inside the NTZ and grey dots, outside the NTZ. Species code in Table 1 (B) Biplot of the Redundancy Analysis connecting the monitored years with grey lines within the protection levels. Font colors indicate the protection level (Blue inside the NTZ, Grey outside the NTZ). (For interpretation of the references to color in this figure legend, the reader is referred to the Web version of this article.)

assemblages occurred over this long-term study (Fig. 2B).

3.2. Long-term trends of the main macroalgal species inside and outside the NTZ

The cover of the main macroalgal communities was homogeneous between the protected and the non-protected locations (inside/outside NTZ) (Fig. 3). The seasonal species of the genus Dictyota and the perennial Corallina elongata (today also accepted as Ellisolandia elongata) were the dominant seaweed in the study area during Spring, with a mean cover of $60 \quad 15 \%$ and $52 \quad 17.3 \%$ (Mean SD), respectively, across the eight monitored sites over time (Fig. 3). High stability of seaweeds cover 
Table 2

Results of redundancy analysis (RDA) on fourth-root transformed data.

\begin{tabular}{lllll}
\hline Axes & RDA 1 & RDA 2 & RDA 3 & RDA 4 \\
\hline $\begin{array}{l}\text { Eigenvalues } \\
\begin{array}{l}\text { Cumulative percentage variance } \\
\text { of species data }\end{array}\end{array}$ & 2.8765 & 1.4672 & 1.2062 & 0.8398 \\
$\quad$ & 9.92 & 14.98 & 19.14 & $\begin{array}{l}22.03 \\
\text { of species-environment relation }\end{array}$ \\
\hline
\end{tabular}

Table 3

Biplot scores for environmental variables, the coefficient of determination (R2), and their significance using 999 permutations on the RDA results.

\begin{tabular}{lccll}
\hline Variable & RDA 1 & RDA 2 & $\mathrm{R}^{2}$ & $\mathrm{p}(>\mathrm{r})$ \\
\hline Protection & 0.97570 & 0.21911 & 0.7393 & 0.001 \\
Sea-urchins & 0.93935 & 0.34297 & 0.4598 & 0.001 \\
SST & 0.62272 & 0.78244 & 0.2954 & 0.001 \\
Chl-a & 0.58762 & 0.80913 & 0.0859 & 0.043 \\
\hline
\end{tabular}

SST:Surface Seawater Temperature. Chl-a: Chlorophyll-a as proxy of nutrients.

over the fifteen years was found in most of the species in both protection levels. Annual changes in the species cover were detected simultaneously throughout the fifteen years in the protected NTZ and unprotected zones, suggesting the same variability on algal community drivers and the similar impact of stressors in both levels of protection (Fig. 3).

The coefficient of variation showed a consistency of the total macroalgal cover estimates over time in both protection levels (Fig. 4A). For the particular species A. armata, Halopteris scoparia, W. penicillata, and $M$. alternans, CV pairwise comparisons showed differences within levels of protection being $A$. armata and $H$. scoparia more variable outside the NTZ while the abundances of $W$. pencillata and $M$. alternans were more variable inside the protected area (Fig. 4B, Table 1 supplementary). Among all the most abundant species, the canopy-forming species Treptacantha elegans showed the highest variability (Fig. 4B).

Short-term changes in macroalgal abundance such as the observed after the 2008 extraordinary storm occurred in the studied period (Fig. 3), but these were not significant over all the multi-year monitoring for the majority of the species (Table 4). Only three of the fourteen dominant species showed differences in their cover across protection levels (Table 4). In spite of the very low cover, the seasonal growing naturalized alga $A$. armata and the perennial canopy-forming T. elegans were more abundant inside the NTZ than outside. In contrast, the seasonal growing species $W$. penicillata was the most characteristic species outside the NTZ (Fig. 3, Table 4). While L. obtusa increased its relative cover over the study period (Fig. 3, Table 4) the calcareous algae C. elongata and Jania rubens decreased over the study period but only outside the NTZ (Fig. 3, Table 4).

\section{Discussion}

Our results revealed that the coastal macroalgal assemblages of the

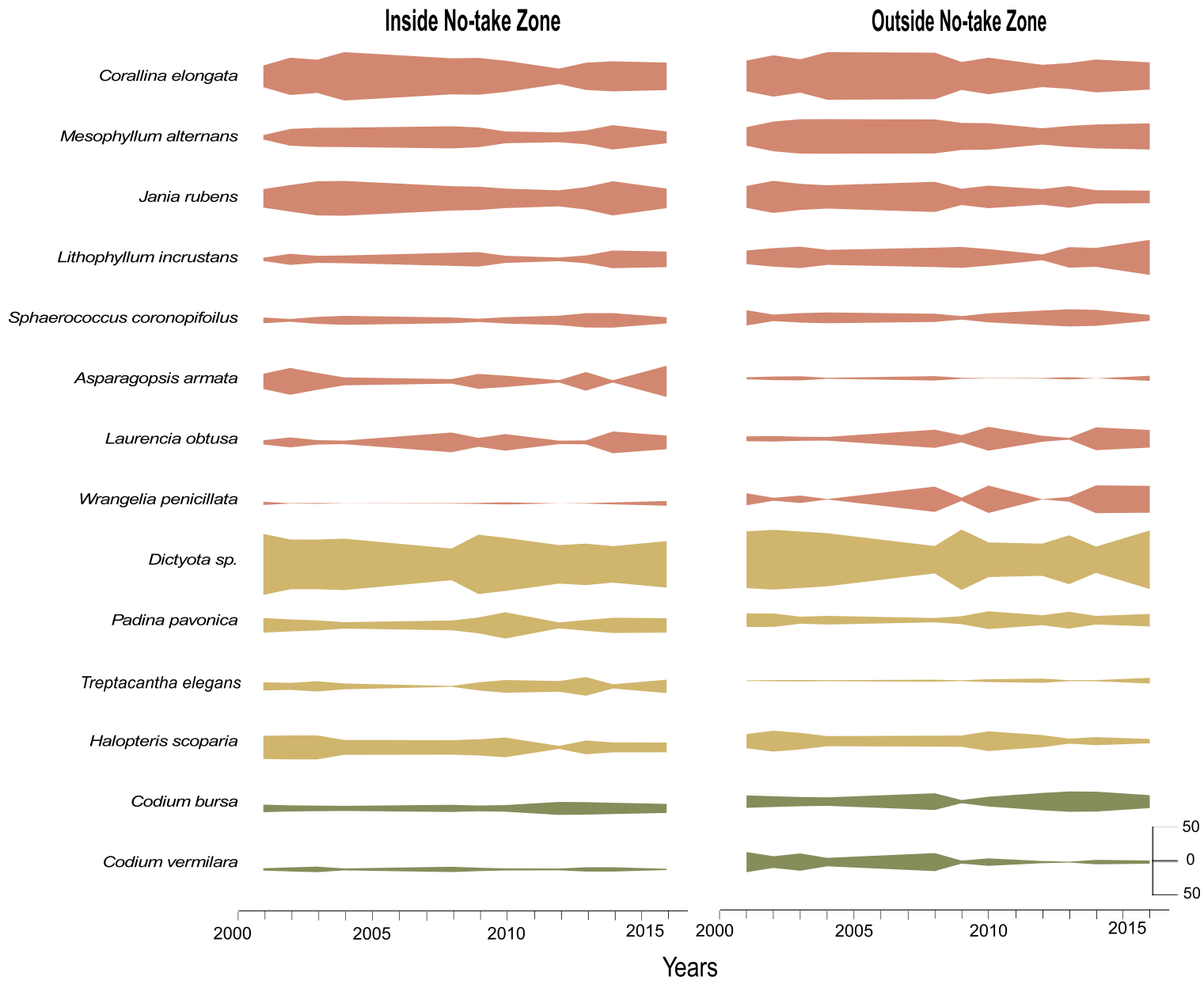

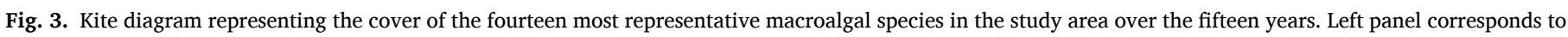

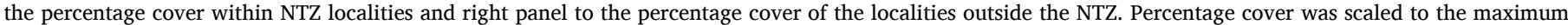

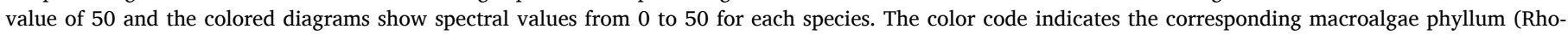

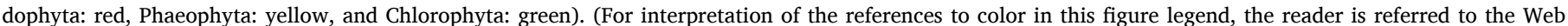
version of this article.) 

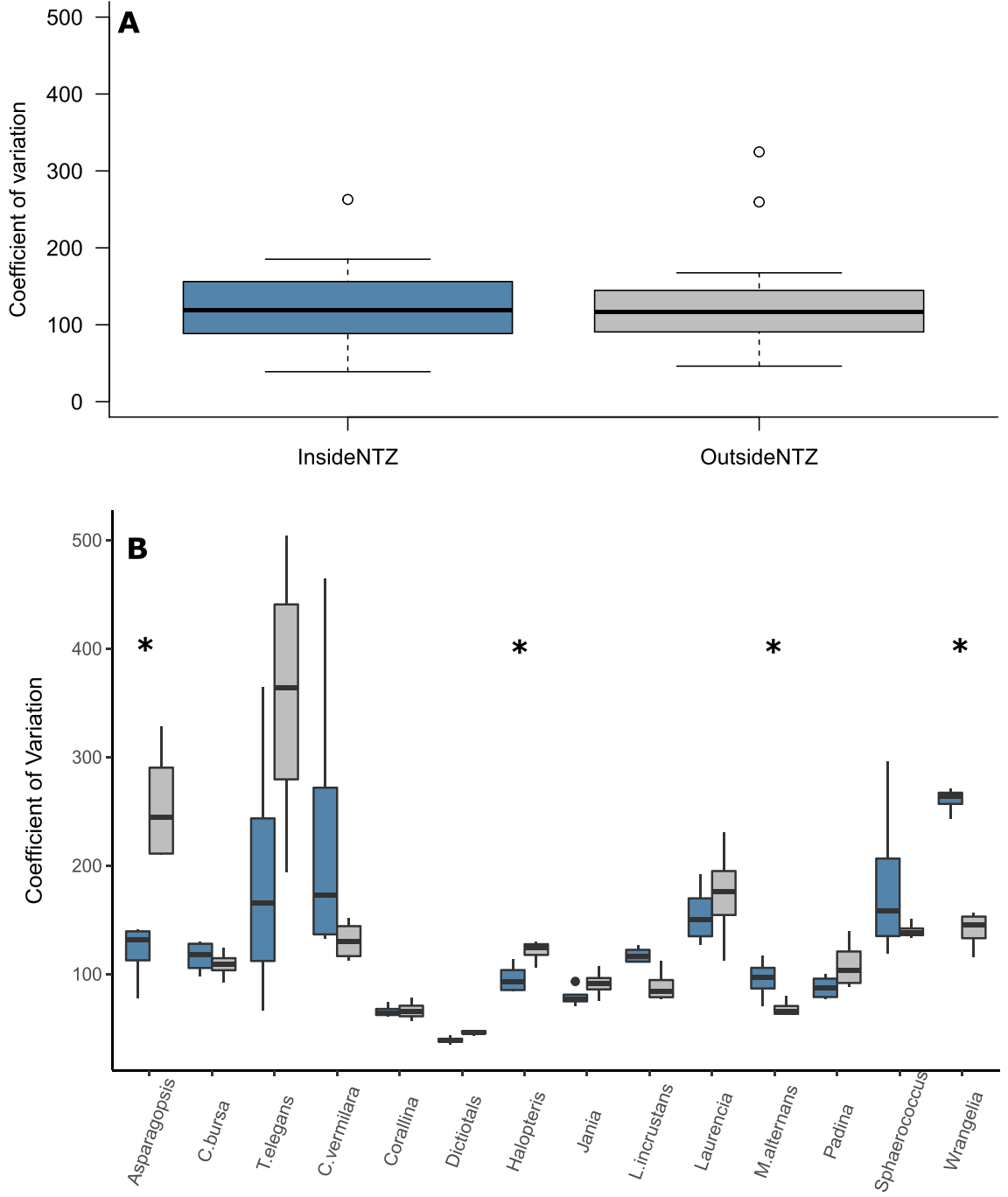

Fig. 4. Coefficients of Variation (CVs) over time. Blue color represents the values inside the NTZ and grey color the values outside the NTZ. (A) Boxplot showing withinprotection CVs in total macroalgae cover (inside/outside the NTZ). (B) Boxplot showing CVs in the cover of the fourteen main macroalgae species within protection levels. ' $*$ ' indicates significance differences $(\mathrm{p}<0.05)$ in pair means using Tukey pairwise comparison. Species code in Table 1. (For interpretation of the references to color in this figure legend, the reader is referred to the Web version of this article.)

Table 4

Generalized Linear Model manyglm results (Deviation test statistic, p-value) of macroalgal cover (Percentage $/ 0.25 \mathrm{~m}^{2}$ ) Df: degrees of freedom. Bold indicates $\mathrm{p}<0.05$. ‘' indicates interaction. Species code in Table 1.

\begin{tabular}{|c|c|c|c|c|c|c|}
\hline Source & Df & Asparagopsis & Dictyota & T. elegans & C. vermilara & C. bursa \\
\hline Protection & 1 & $25.093,0.001$ & $2.45,0.596$ & $23.324,0.001$ & $5.545,0.209$ & $2.26,0.607$ \\
\hline Time & 10 & $31.461,0.343$ & $30.58,0.343$ & $25.542,0.547$ & $26.429,0.531$ & $39.415,0.112$ \\
\hline Protection:Time & 9 & $17.314,0.088$ & $16.605,0.088$ & $16.276,0.088$ & $28.503,0.020$ & $6.463,0.088$ \\
\hline Source & Df & Halopteris & Laurencia & Padina & Sphaerococcus & Wrangelia \\
\hline Protection & 1 & $0.001,0.993$ & $0.14,0.993$ & $0.108,0.993$ & $0.089,0.993$ & $14.214,0.006$ \\
\hline Time & 10 & $29.86,0.354$ & $47.096,0.010$ & $27.475,0.489$ & $26.928,0.510$ & $40.56,0.112$ \\
\hline Protection:Time & 9 & $18.854,0.061$ & $13.157,0.088$ & $19.008,0.061$ & $13.115,0.088$ & $11.207,0.088$ \\
\hline Source & Df & Coralina & Jania & L. Incrustans & M. Alternans & \\
\hline Protection & 1 & $0.933,0.889$ & $1.62,0.744$ & $8.749,0.052$ & $3.736,0.391$ & \\
\hline Time & 10 & $34.044,0.228$ & $21.578,0.547$ & $33.851,0.228$ & $35.31,0.169$ & \\
\hline Protection:Time & 9 & $26.231,0.025$ & $24.497,0.025$ & $18.032,0.077$ & $15.289,0.088$ & \\
\hline
\end{tabular}

Montgrí, the Illes Medes and the Baix Ter Natural Park were stable and similar in total algal cover inside and outside the protected NTZ over the fifteen years of study with no species replacement, although some variability were observed between years. The communities were dominated by the perennial species $C$. elongata and the seasonal Dictyota species. Corallina elongata has been previously described as predominant species subjected to moderate pollution (Díez et al., 1999; Soltan et al.,
2001). Species related to high-quality environmental requirements, such as Cystoseira sensu lato species (Thibaut et al., 2005; Mangialajo et al., 2008). were less abundant in the study area. In addition to environmental quality, bottom-up (herbivorous control) and top-down (resources control) processes interactively influence the structure of macroalgal benthic communities (Korpinen et al., 2007; Smith et al., 2010). As we expected, bottom-up forces such as spring nutrient 
concentration and the ordination of the majority of seasonal algal species were associated to water temperature, in which herbivory showed the weakest influence (except for A. armata and W. penicillata). Contrarily, top-down forces may play a role in determining the abundance of fucoids such as the canopy-forming Cystoseira sensu lato species and the encrusting coralline algae species. It has been extensively documented that increased abundance of grazers feeding on algal beds can significantly change the structure of shallow benthic communities (Airoldi and Beck, 2007; Filbee-Dexter and Scheibling, 2014; Mineur et al., 2015).

The sea urchin Paracentrotus lividus is the most important herbivore in the study area, playing an important role in structuring algal communities (Sala and Zabala, 1996; Palacín et al., 1998; Hereu et al., 2008). As P. lividus preferentially graze on fleshy algae (Privitera et al., 2008), encrusting algae showed a positive relationship to the presence of sea urchins. Although many studies have been demonstrate that herbivorous fishes may also influence the structure of the benthic assemblages (Verges et al., 2009; Gianni et al., 2017), we did not consider them because there are not evidences of the effect of protection on the abundance of the unique herbivore fish in this area, Sarpa salpa (Prado et al., 2007). Moreover, their effects on macroalgal beds in the studied area are weaker than the sea urchins one (Hereu, 2006; Hereu et al., 2008). This could be explained by the feeding preference and behavior of Sarpa salpa, the only strictly herbivorous fish in this area (Sala and Boudouresque, 1997). S. salpa has shown preference for high palatable plants such as seagrasses or fleshy algae (Verges et al., 2009; Ali et al., 2017). In addition, fishes feeding behavior differ from the sea urchins as fishes bite the leaf while sea urchins graze the entire thalli which could deplet large algal extensions (Hereu, 2006; Jadot et al., 2006).

No-take marine reserves can indirectly restore the original trophic cascades recovering the abundance of herbivores' predators (Sala and Giakoumi, 2017) and controlling the herbivore populations (Medrano et al., 2019). Results of this study go one step further in the trophic cascade of the studied area and also demonstrate that No-Take marine reserves can influence the abundance of the canopy-forming Cystoseira sensu lato species, being more abundant in protected areas (as reported for the same studied NTZ in Sala et al., 2012). Without losing sight of the large variability observed in the cover of perennial canopy-forming T. elegans over time suggesting a high influence of local conditions on this species, this results reinforces the usefulness of marine reserves as conservation tools also at lower trophic levels, which is particularly relevant when considering the global decline of Cystoseira sensu lato species. in the Mediterranean Sea (Thibaut et al., 2005, 2014). Despite Cystoseira sensu lato species were not the dominant species in the macroalgal beds of the Natural Park, their loss or replacement could have major consequences for many associate organisms (e.g., lowering fish recruitment, Cheminee et al., 2013). On the other hand, Codium vermilara showed completely opposite ordination relative to the main drivers and stressors than Cystoseira spp. This result support the hypothesis of C. vermilara could have been replaced by Cystoseira sensu lato species assemblages after their historical decline in the NW Mediterranean Sea (Ricart et al., 2018). Regarding the less abundant species, our study confirms the effect of protection for A. armata, which was already suggested by Sala and Boudouresque (1997). This unpalatable red alga was practically absent outside the NTZ, but showed a high variability over the fifteen years. The reverse pattern was observed for $W$. penicillata species, more abundant and less variable outside the NTZ. We did not detect the influence of any of the studied drivers in the filamentous turf forming Ceramium ciliatum, probably because of their short life cycle (Bologa et al., 1995).

Extreme climate events such as severe storms have been also considered as potential drivers eroding macroalgal beds (Navarro et al., 2011; Borja et al., 2018; Capdevila et al., 2019). An exceptionally storm with drastic consequences on benthic communities occurred in the study area in 2008 (Mateo and Garcia-Rubies, 2012; Sanchez-Vidal et al., 2012), where we observed a short-term effect in the macroalgal communities exerted by the storm like those previously reported in other studies (Navarro et al., 2011; Micheli et al., 2016; Maggi et al., 2018). Benefiting from the available space that resulted from the storm, a rapid increase of highly seasonal Dictyota species were observed right after the storm (the year 2009), while most of the perennial species decreased. Over the following years, the abundance and structure of the main macroalgal assemblages recovered swiftly to pre-storm values and no long-term impacts were observed, indicating that impacts of a single extraordinary storm on rocky-shallow algal communities may be reversed relatively quickly. However, we should consider that an increase in the intensity and frequency of extreme climatic events, such as extraordinary storms, has been observed since 1950 and is expected to increase in the future (IPCC et al., 2014; Reguero et al., 2019), especially in the Mediterranean, which has been highlighted as a hotspot of ongoing climate change (IPCC et al., 2014; Cramer et al., 2018). Our results stress the importance of increasing spatial and temporal scales to better understand the natural variability of the marine communities and do not misunderstand the changes observed in algal assemblages (Lindenmayer et al., 2012). If the same dataset of this study would have been used to describe the consequences of this extraordinary storm right after the impact, notable differences could have been described.

Despite the relevance of monitoring algal communities, it is important to highlight some limitations of this study. In order to effectively document long-term changes of the macroalgal assemblages structure over time, we prioritize a broad view of the community by monitoring the algal cover of the main species in our study area and missing the minority species. This methodology allows to maintain long-term monitoring programs, involving different observers due to the easy identification of a reduced number of species but it is not the optimal ecological design in order to analyze other community indexes such as biodiversity or richness. Many studies pool species into functional groups, as a way to predict algal community composition (Steneck and Dethier, 1994). This reduction of species-specific information is generally accepted at the expense of a broader view of the changes in community structure. However, it is important to stress that this approach hinders to detect some important changes at the species level because different algal species have different responses to herbivores and other perturbations independently on their functional group (Hereu et al., 2008). Most of the results exposed here would have been lost or misinterpreted working with functional groups such as the high variability of T. elegans, which would have been pooled in the erect algae group.

A major insight of this study is the absence of major shifts in species replacement and abundance and the null effect of protection in the most important macroalgal communities in the rocky-shallow infralittoral zone of the studied area. Differences only regard the less abundant species, among them the canopy-forming Treptacantha elegans which took preference inside the protected NTZ. These results provide a current baseline of algal communities and contribute to the literature on the role of NTZs marine reserves in the benthic communities.

\section{Authors' contributions}

$\mathrm{MZ}, \mathrm{BH}$, and $\mathrm{CL}$ designed and began the long-term monitoring. MZ, BH, CL, EA, AM, PC MPE, and IMS conducted most of the fieldwork presented in this study. AM analyzed the data and wrote the first version of the manuscript with reviews and editing from all the authors.

\section{Funding}

This work was supported by the long-term monitoring programme of the Natural Park of Cap de Creus and the Natural Park of Montgrí, Illes Medes and Baix Ter, the Medes Islands and the Baix Ter protected areas (public agreement PTOP- 2017-130, Departament de Territori i Sostenibilitat of the Generalitat de Catalunya) and by the European Union's Horizon 2020 research and innovation programme under grant agreement No 689518 (MERCES). This output reflects only the authors' view, 
and the European Union cannot be held responsible for any use of the information contained herein that may be made. All the authors are part of the MedRecover research group 2017SGR-1521 (www.medrecover. org).

\section{Declaration of competing interest}

The authors declare that they have no known competing financial interests or personal relationships that could have appeared to influence the work reported in this paper.

\section{Acknowledgements}

We are gratefully acknowledged to Josep Pascual, who measured and provided the seawater temperature data. We thank C. Bonaviri, A.L. Dedeu, L. Navarro, N. Teixido, and F. Tomas for their assistance in the fieldwork during the long-term monitoring. We want to recognize Graciel.la Rovira, who was not involved in the research group by the monitored period in this study but is a key figure to continue studying these communities over the following years.

\section{Appendix A. Supplementary data}

Supplementary data to this article can be found online at https://doi. org/10.1016/j.marenvres.2019.104826.

\section{References}

Airoldi, L., Beck, M.W., 2007. Loss, status and trends for coastal marine habitats of Europe. In: Oceanography And Marine Biology: an Annual Review. Aberdeen University Press/Allen and Unwin. CRC Press, London, pp. 357-417. ISSN 00783218.

Ali, R., El-Etreby, S., Alwany, M., Ahmed, A., 2017. Food and Feeding Habits of Sarpa salpa Salema (Family: Sparidae) in the Libyan Coast of the Mediterranean Sea

Babcock, R.C., Shears, N.T., Alcala, A.C., Barrett, N.S., Edgar, G.J., Lafferty, K.D., McClanahan, T.R., Russ, G.R., 2010. Decadal trends in marine reserves reveal differential rates of change in direct and indirect effects. Proc. Natl. Acad. Sci. 107 (43), 18256-18261. https://doi.org/10.1073/pnas.0908012107.

Ballesteros, E., 1991. In: Ros, J.D., Prat, N. (Eds.), Structure and Dynamics of NorthWestern Mediterranean Phytobenthic Communities: a Conceptual Model. Homage to Ramon Margalef, or, Why There Is Such Pleasure in Studying Nature, Oecologia Aquatica, vol.10, pp. 223-242, 1991.

Ballesteros, E., Sala, E., Garrabou, J., Zabala, M., 1998. Community structure and frond size distribution of a deep water stand of Cystoseira spinosa (Phaeophyta) in the Northwestern Mediterranean. Eur. J. Phycol. 33 (2), 121-128. https://doi.org/ $10.1080 / 09670269810001736613$.

Bologa, A.S., Bodeanu, N., Petran, A., Tiganus, V., Zaitsev, Y.P., 1995. Major modifications of the Black Sea benthic and planktonic biota in the last three decades. Bull. Inst. Oceanogr. (Monaco) 1, 85-110.

Blamey, L.K., Bolton, J.J., 2018. The economic value of South African kelp forests and temperate reefs: past, present and future. J. Mar. Syst. 188, 172-181. https://doi. org/10.1016/j.jmarsys.2017.06.003.

Borja, A., Chust, G., Fontan, A., Garmendia, J.M., Uyarra, M.C., 2018. Long-term decline of the canopy-forming algae Gelidium corneum, associated to extreme wave events and reduced sunlight hours, in the southeastern Bay of Biscay. Estuar. Coast Shelf Sci. 205, 152-160.

Brodie, J., De'Ath, G., Devlin, M., Furnas, M., Wright, M., 2007. Spatial and temporal patterns of near-surface chlorophyll a in the Great Barrier Reef lagoon. Mar. Freshw. Res. 58 (4), 342-353. https://doi.org/10.1071/MF06236.

Capdevila, P., Hereu, B., Salguero-Gomez, R., Rovira, G.L., Medrano, A., Cebrian, E., Garrabou, J., Kersting, D., Linares, C., 2019. Warming impacts on early life stages increase the vulnerability and delay the population recovery of a long-lived habitat forming macroalga. J. Ecol. 107 (3), 1129-1140. https://doi.org/10.1111/13652745.13090.

Cheminee, A., Sala, E., Pastor, J., Bodilis, P., Thiriet, P., Mangialajo, L., Cottalorda, J.-M., Francour, P., 2013. Nursery value of Cystoseira forests for Mediterranean rocky reef fishes. J. Exp. Mar. Biol. Ecol. 442, 70-79. https://doi.org/10.1016/j jembe.2013.02.003.

Cramer, W., Guiot, J., Fader, M., Garrabou, J., Gattuso, J.P., Iglesias, A., et al., 2018 Climate change and interconnected risks to sustainable development in the Mediterranean. Nat. Clim. Chang. 1 https://doi.org/10.1038/s41558-018-0299-2.

Díez, I., Secilla, A., Santolaria, A., Gorostiaga, J.M., 1999. Phytobenthic intertidal community structure along an environmental pollution gradient. Mar. Pollut. Bull. 38 (6), 463-472. https://doi.org/10.1016/S0025-326X(98)90161-8.

Duarte, C.M., Cebrian, J., 1996. The fate of marine autotrophic production. Limnol. Oceanogr. 41 (8), 1758-1766.
Filbee-Dexter, K., Scheibling, R.E., 2014. Sea urchin barrens as alternative stable states of collapsed kelp ecosystems. Mar. Ecol.: Prog. Ser. 495, 1-25. https://doi.org/ 10.3354/meps10573.

Gianni, F., Bartolini, F., Pey, A., Laurent, M., Martins, G.M., Airoldi, L., Mangialajo, L., 2017. Threats to large brown algal forests in temperate seas: the overlooked role of native herbivorous fish. Sci. Rep. 7 (1), 6012. https://doi.org/10.1038/s41598-01706394-7.

Gross, K., Edmunds, P.J., 2015. Stability of Caribbean coral communities quantified by long-term monitoring and autoregression models. Ecology 96 (7), 1812-1822. https://doi.org/10.1890/14-0941.1.

Guidetti, P., 2006. Marine reserves reestablish lost predatory interactions and cause community changes in rocky reefs. Ecol. Appl. 16 (3), 963-976. https://doi.org/ 10.1890/1051-0761.

Halpern, B.S., Selkoe, K.A., Micheli, F., Kappel, C.V., 2007. Evaluating and ranking the vulnerability of global marine ecosystems to anthropogenic threats. Conserv. Biol. 21 (5), 1301-1315. https://doi.org/10.1111/j.1523-1739.2007.00752.x.

Hereu, B., 2005. Movement patterns of the sea urchin Paracentrotus lividus in a marine reserve and an unprotected area in the NW Mediterranean. Marine Ecology 26 (1), 54-62. https://doi.org/10.1111/j.1439-0485.2005.00038.x. In press.

Hereu, B., 2006. Depletion of palatable algae by sea urchins and fishes in a Mediterranean subtidal community. Mar. Ecol. Prog. Ser. 313, 95-103.

Hereu, B., Zabala, M., Sala, E., 2008. Multiple controls of community structure and dynamics in a sublittoral marine environment. Ecology 89 (12), 3423-3435. https:// doi.org/10.1890/07-0613.1.

Hereu, B., Linares, C., Sala, E., Garrabou, J., Garcia-Rubies, A., Diaz, D., Zabala, M., 2012. Multiple processes regulate long-term population dynamics of sea urchins on Mediterranean rocky reefs. PLoS One 7 (5), e36901. https://doi.org/10.1371/ journal.pone.0036901.

IPCC, 2014. Core writing Team. In: Pachauri, R.K., Meyer, L.A. (Eds.), Climate Change 2014: Synthesis Report. Contribution of Working Groups I, II and III to the Fifth Assessment Report of the Intergovernmental Panel on Climate Change. IPCC, Geneva, Switzerland, p. 151.

Jadot, C., Donnay, A., Acolas, M.L., Cornet, Y., Begout Anras, M.L., 2006. Activity patterns, home-range size, and habitat utilization of Sarpa salpa (Teleostei: sparidae) in the Mediterranean Sea. ICES (Int. Counc. Explor. Sea) J. Mar. Sci. 63 (1), 128-139.

Jones, C.G., Lawton, J.H., Shachak, M., 1994. Organisms as ecosystem engineers. In: Ecosystem Management. Springer, New York, NY, pp. 130-147.

Krause-Jensen, D., Duarte, C.M., 2016. Substantial role of macroalgae in marine carbon sequestration. Nat. Geosci. 9 (10), 737. https://doi.org/10.1038/NGEO2790.

Kirkman, H., Kirkman, J., 2000. Long-term seagrass meadow monitoring near Perth, Western Australia. Aquat. Bot. 67 (4), 319-332. https://doi.org/10.1016/S03043770(00)00097-8.

Korpinen, S., Jormalainen, V., Honkanen, T., 2007. Bottom-up and cascading top-down control of macroalgae along a depth gradient. J. Exp. Mar. Biol. Ecol. 343 (1), 52-63. https://doi.org/10.1016/j.jembe.2006.11.012.

Lindenmayer, D.B., Likens, G.E., Andersen, A., Bowman, D., Bull, C.M., Burns, E., et al., 2012. Value of long-term ecological studies. Austral Ecol. 37 (7), 745-757. https:// doi.org/10.1111/j.1442-9993.2011.02351.x.

Ling, S.D., Johnson, C.R., Frusher, S.D., Ridgway, K.R., 2009. Overfishing reduces resilience of kelp beds to climate-driven catastrophic phase shift. Proc. Natl. Acad. Sci. 106 (52), 22341-22345. https://doi.org/10.1073/pnas.0907529106.

Ling, S.D., Scheibling, R.E., Rassweiler, A., Johnson, C.R., Shears, N., Connell, S.D., et al., 2015. Global regime shift dynamics of catastrophic sea urchin overgrazing. Philos. Trans. R. Soc. Biol. Sci. 370 (1659) https://doi.org/10.1098/rstb.2013.0269, 20130269.

Macpherson, E., Gordoa, A., Garcia-Rubies, A., 2002. Biomass size spectra in littoral fishes in protected and unprotected areas in the NW Mediterranean. Estuarine. Coast Shelf Sci. 55 (5), 777-788.

Maggi, E., Puccinelli, E., Benedetti-Cecchi, L., 2018. Ecological feedback mechanisms and variable disturbance regimes: the uncertain future of Mediterranean macroalgal forests. Mar. Environ. Res. 140, 342-357. https://doi.org/10.1016/j. marenvres.2018.07.002.

Mangialajo, L., Chiantore, M., Cattaneo-Vietti, R., 2008. Loss of fucoid algae along a gradient of urbanisation, and structure of benthic assemblages. Mar. Ecol. Prog. Ser. 358, 63-74. https://doi.org/10.3354/meps07400.

Mateo, M.A., Garcia-Rubies, T., 2012. Assessment of the Ecological Impact of the Extreme Storm of Sant Esteve's Day (26 December 2008) on the Littoral Ecosystems of the North Mediterranean Spanish Coasts. Centro de Estudios Avanzados de Blanes, Consejo Superior de Investigaciones Científicas, Blanes, Spain, p. 318. Final Report (PIEC 200430E599).

Medrano, A., Linares, C., Aspillaga, E., Capdevila, P., Montero-Serra, I., Pages-Escola, M., Hereu, B., 2019. No-take marine reserves control the recovery of sea urchin populations after mass mortality events. Mar. Environ. Res. 145, 147-154. https:// doi.org/10.1016/j.marenvres.2019.02.013.

Micheli, F., Heiman, K.W., Kappel, C.V., Martone, R.G., Sethi, S.A., Osio, G.C., et al., 2016. Combined impacts of natural and human disturbances on rocky shore communities. Ocean Coast Manag. 126, 42-50. https://doi.org/10.1016/j. ocecoaman.2016.03.014.

Mineur, F., Arenas, F., Assis, J., Davies, A.J., Engelen, A.H., Fernandes, F., Malta, E.-J., Thibaut, T., Nguyen, T.V., Vaz-Pinto, F., Vranken, S., Serrão, E., De Clerck, O., 2015. European seaweeds under pressure: consequences for communities and ecosystem functioning. J. Sea Res. 98, 91-108. https://doi.org/10.1016/j.seares.2014.11.004.

Navarro, L., Ballesteros, E., Linares, C., Hereu, B., et al., 2011. Spatial and tempora variability of deep-water algal assemblages in the Northwestern Mediterranean: The effects of an exceptional storm. Estuarine, Coastal and Shelf Science 95 (1), 52-58. 
Oksanen, J., Blanchet, F.G., Friendly, M., Kindt, R., Legendre, P., McGlinn, D., Minchin, P.R., O'Hara, R.B., Simpson, G.L., Solymos, P.M., Stevens, H.H., Szoecs, E., Wagner, H., 2017. vegan: community Ecology Package. R package version 2.4-2. https://CRAN.R-project.org/package vegan.

Palacín, C., Giribet, G., Carner, S., Dantart, L., Turon, X., 1998. Low densities of sea urchins influence the structure of algal assemblages in the western Mediterranean. J. Sea Res. 39 (3-4), 281-290. https://doi.org/10.1016/S1385-1101(97)00061-0.

Prado, P., Tomas, F., Alcoverro, T., Romero, J., 2007. Extensive direct measurements of Posidonia oceanica defoliation confirm the importance of herbivory in temperate seagrass meadows. Mar. Ecol. Prog. Ser. 340, 63-71.

Privitera, D., Chiantore, M., Mangialajo, L., Glavic, N., Kozul, W., Cattaneo-Vietti, R., 2008. Inter-and intra-specific competition between Paracentrotus lividus and Arbacia lixula in resource-limited barren areas. J. Sea Res. 60 (3), 184-192. https:// doi.org/10.1016/j.seares.2008.07.001.

R Core Team, 2017. R: A Language and Environment for Statistical Computing. R Foundation for Statistical Computing, Vienna, Austria. https://www.R-project.org/.

Reguero, B.G., Losada, I.J., Mendez, F.J., 2019. A recent increase in global wave powe as a consequence of oceanic warming. Nat. Commun. 10 (1), 205. https://doi.org/ 10.1038/s41467-018-08066-0.

Ricart, A.M., García, M., Weitzmann, B., Linares, C., Hereu, B., Ballesteros, E., 2018. Long-term shifts in the north western Mediterranean coastal seascape: the habitatforming seaweed Codium vermilara. Mar. Pollut. Bull. 127, 334-341. https://doi. org/10.1016/j.marpolbul.2017.12.019.

Sala, E., Zabala, M., 1996. Fish predation and the structure of the sea urchin Paracentrotus lividus populations in the NW Mediterranean. Mar. Ecol. Prog. Ser. 71-81. https://doi.org/10.3354/meps140071.

Sala, E., 1997. Fish predators and scavengers of the sea urchin Paracentrotus lividus in protected areas of the north-west Mediterranean Sea. Mar. Biol. 129 (3), 531-539.

Sala, E., Ballesteros, E., 1997. Partitioning of space and food resources by three fish of the genus Diplodus (Sparidae) in a Mediterranean rocky infralittoral ecosystem. Mar Ecol. Prog. Ser. 152, 273-283. https://doi.org/10.3354/meps152273.

Sala, E., Boudouresque, C.F., 1997. The role of fishes in the organization of a Mediterranean sublittoral community.: I: algal communities. J. Exp. Mar. Biol. Ecol. 212 (1), 25-44. https://doi.org/10.1016/S0022-0981(96)02745-1.

Sala, E., Ballesteros, E., Dendrinos, P., Di Franco, A., Ferretti, F., Foley, D., et al., 2012 The structure of Mediterranean rocky reef ecosystems across environmental and human gradients, and conservation implications. PLoS One 7 (2), e32742. https:// doi.org/10.1371/journal.pone.0032742

Sala, E., Giakoumi, S., Pendleton, Linwood, 2017. No-take marine reserves are the most effective protected areas in the ocean. ICES (Int. Counc. Explor. Sea) J. Mar. Sci. 75 (3), 1166-1168. https://doi.org/10.1093/icesjms/fsx059.

Sanchez-Vidal, A., Canals, M., Calafat, A.M., Lastras, G., Pedrosa-Pamies, R., Menendez, M., et al., 2012. Impacts on the deep-sea ecosystem by a severe coastal storm. PLoS One 7 (1), e30395. https://doi.org/10.1371/journal.pone.0030395.
Smale, D.A., Vance, T., 2016. Climate-driven shifts in species' distributions may exacerbate the impacts of storm disturbances on North-east Atlantic kelp forests. Mar. Freshw. Res. 67 (1), 65-74. https://doi.org/10.1071/MF14155.

Shears, N.T., Babcock, R.C., 2002. Marine reserves demonstrate top-down control of community structure on temperate reefs. Oecologia 132 (1), 131-142. https://doi. org/10.1007/s00442-002-0920-x.

Smith, J.E., Hunter, C.L., Smith, C.M., 2010. The effects of top-down versus bottom-up control on benthic coral reef community structure. Oecologia 163 (2), 497-507. https://doi.org/10.1007/s00442-009-1546-z.

Soltan, D., Verlaque, M., Boudouresque, C.F., Francour, P., 2001. Changes in macroalgal communities in the vicinity of a Mediterranean sewage outfall after the setting up of a treatment plant. Mar. Pollut. Bull. 42 (1), 59-70. https://doi.org/10.1016/S0025326X(00)00116-8.

Steneck, R.S., Dethier, M.N., 1994. A functional group approach to the structure of algaldominated communities. Oikos 69 (3), 476-498.

Steneck, R.S., Graham, M.H., Bourque, B.J., Corbett, D., Erlandson, J.M., Estes, J.A., Tegner, M.J., 2002. Kelp forest ecosystems: biodiversity, stability, resilience and future. Environ. Conserv. 29 (4), 436-459. https://doi.org/10.1017/ S0376892902000322.

Teagle, H., Hawkins, S.J., Moore, P.J., Smale, D.A., 2017. The role of kelp species as biogenic habitat formers in coastal marine ecosystems. J. Exp. Mar. Biol. Ecol. 492, 81-98. https://doi.org/10.1016/j.jembe.2017.01.017.

Thibaut, T., Pinedo, S., Torras, X., Ballesteros, E., 2005. Long-term decline of the populations of fucales (Cystoseira spp. and sargassum spp.) in the alberes coast (France, North-Western mediterranean). Mar. Pollut. Bull. 50 (12), 1472-1489. https://doi.org/10.1016/j.marpolbul.2005.06.014.

Thibaut, T., Blanfune, A., Boudouresque, C.F., Verlaque, M., 2014. Decline and local extinction of Fucales in French Riviera: the harbinger of future extinctions? Mediterr. Mar. Sci. 16 (1), 206-224. https://doi.org/10.12681/mms.1032.

Verges, A., Alcoverro, T., Ballesteros, E., 2009. Role of fish herbivory in structuring the vertical distribution of canopy algae Cystoseira spp. in the Mediterranean Sea. Mar. Ecol.: Prog. Ser. 375, 1-11.

Van Den Wollenberg, A.L., 1977. Redundancy analysis an alternative for canonical correlation analysis. Psychometrika 42 (2), 207-219.

Wang, Y., Naumann, U., Wright, S., Eddelbuettel, D., Warton, D., 2017. Mvabund statistical methods for analysing multivariate abundance data. $\mathrm{R}$ package version 3.12.3. https://CRAN.R-project.org/package mvabund.

Wernberg, T., Bennett, S., Babcock, R.C., De Bettignies, T., Cure, K., Depczynski, M., et al., 2016. Climate-driven regime shift of a temperate marine ecosystem. Science 353 (6295), 169-172. https://doi.org/10.1126/science.aad8745.

Zabala, M., Ballesteros, E., 1989. Surface-dependent strategies and energy flux in benthic marine communities or, why corals do not exist in the Mediterranean. Sci. Mar. 53, $1-15$. 